Volume and Issues Obtainable at Center for Sustainability Research and Consultancy
Sustainable Business and Society in Emerging Economies
ISSN: 2708-2172 \& (E): 2708-2504
Volume 3: Issue 3 September 2021
¿SRட
Journal homepage: www.publishing.globalcsrc.org/sbsee

\title{
Technical Efficiency Determinants of Islamic Banks: How Do Countries Differ
}

Muhammad Hanif Akhtar, Department of Commerce, Bahauddin Zakariya University, Multan, Pakistan

*Muhammad Ramzan Sheikh, School of Economics, Bahauddin Zakariya University, Multan, Pakistan Muzammil Ahmad, Departemnt of Commerce, Punjab Group of Colleges, Multan, Pakistan Muhammad Bashir Khan, Department of Government and Public Policy, National Defense University, Islamabad, Pakistan

*Corresponding author's email: ramzansheikh@bzu.edu.pk

\begin{tabular}{l}
\hline ARTICLE DETAILS \\
\hline History \\
Revised format: Aug 2021 \\
Available Online: Sep 2021 \\
\hline Keywords
\end{tabular}

Keywords

Technical Efficiency,

Data Envelopment, Analysis, Islamic Banks,

Z-score.

Jel Classification

M1, M12

\section{ABSTRACT}

Purpose: This paper analyzes the determinants of technical efficiency of Islamic banks in eight of the Islamic countries. These include Brunei Darussalam, Jordan, Indonesia, Pakistan, Malaysia, Turkey, Saudi Arabia, and the UAE.

Design/Methodology/Approach: A quarterly panel data on eight Islamic countries' banks during the period of 2014 to 2019 is used for the analysis.

Findings: The overall outcomes of the study indicate that banks in KSA, UAE, and Malaysia are found to be more efficient than their counterparts in other five countries in the sample. Banks from KSA and UAE have the same average technical efficiency scores while banks in Malaysia and Jordan tend to share similar average technical efficiency scores. Findings of the study reveal that variables like bank size, return on equity, and liquid asset ratio have a positive and significant bearing while factors like GDP growth rate, Z-score, and capital adequacy ratio have a negative and significant impact on technical efficiency of Islamic banks.

Implications/Originality/Value: The study puts forward some useful policy implications both for managers of banks and policymakers of countries in the sample.

(C2021 The authors, under a Creative Commons Attribution- Non

Recommended citation: Akhtar, M. H., Sheikh, M. R., Ahmad, M. and Khan, M. B. (2021). Technical Efficiency Determinants of Islamic Banks: How Do Countries Differ? Sustainable Business and Society in Emerging Economies, 3 (3), 163-175.

\section{Introduction}

The financial sector plays a considerable role in development of an economy. Studies by Abeka et al., (2021); Siriki et al., (2021); Kavya and Shijin (2020); Ratsimalahelo and Barry (2010); Abu-Bader and Abu-Qarn (2008); Galindo et al., (2007); Shan and Jianhong (2006); etc. claim that there is a direct association between financial development and economic growth. Financial institutions need to work at a significantly higher level of efficiency to support economic growth. While banks become more efficient, 
the level of economic development accelerates (Banna et al., 2020). Banking is considered as one of the fundamental segments of financial framework as it broadly influences overall financial stability and economy. It associates economic operators with the financial markets. Banking assumes a significant part in liquidity-based intermediation and links the surplus units with deficit ones through various networks.

Most of the developed and developing countries around the world have deregulated their banking system over the past few years (Ariff and Can, 2008). The basic objective of such reforms is to improve the efficiency, productivity, and profitability of the banking system. Both IMF and the World Bank have also taken steps to improve the efficiency and performance of the financial sector to improve overall economic performance.

Islamic banking is considered one of the fast-growing areas in finance and banking. So, in comparison to other banking systems, this system is a relatively new phenomenon. The Islamic banking system has advanced from minor financial transactions to highly significant financial accounts of the world both in terms of assets size and activities. Compared with traditional banking, it is considered an executable option after the global financial crisis as the development of Islamic funds shelters clients against adverse factors and encourages them towards Islamic products and services (Aysan et al., 2018).

Islamic banking and the financial industry have expanded worldwide during the last three decades due to its huge amount of asset accumulation and the formation of new institutions. To fulfil the growing needs of the corporate sector and individuals, Islamic banks introduce much new investment and financial products. Islamic banks are present globally both in Muslim as well as non-Muslim countries. These banks are working along with conventional banks in almost every Muslim country. Full-fledged Islamic banks and the windows of Islamic banks within conventional banks are two forms of this banking system.

Today, more than 500 financial and banking institutions are included in this industry, with an average growth rate of 15-20\% per annum and this industry has become an important player in the global financial industry. Standard and Poor Global Rankings report indicates that the total wealth of the Islamic banking industry has increased by $2 \%$ in 2018, which was $10 \%$ in 2017 . The total sum of wealth under the management of this industry is forecasted to be $\$ 2.43$ trillion, which is considered below its likelihood of \$4.84 trillion. The popularity in the Islamic banking sector is also growing in Middle East, Africa, and South Asian (MEASA) region, which constitutes assets value to \$2.1 trillion. Sharia-complaint assets belong to $25 \%$ sum of banking assets in GCC and $14 \%$ of the total banking assets are in MEASA region, intimating that Islamic banking proceeds significantly in that region of the world.

Inefficiency may be the main reason for less success in the banking sector (Barr et al, 1994). The banking organizations should be capable to perform more efficiently to assure and support the overall economic growth of a country. In an economic sense, technical efficiency is defined as the ability of a firm to obtain maximum output from a given set of inputs. While in the sense of bank regulators, it is defined as an ongoing and precise measurement of the performance of a bank that permits the allocation of bank wealth more effectively and leads to better utilization of operational activities (Barr et al., 1994).

For financial institutions, the efficiency boosts profitability, a huge quantity of funds, negotiated prices and service specialty for clients. To reduce risk, equity must be strengthened by employing efficiency. (Berger et al., 1997). Consequently, the investigation of Shariah banks is significant on three grounds. Firstly, an increase in efficiency leads to achieve more profits and expand the opportunity of endurance business sectors. Secondly, clients are keen on investigating costs and nature of bank benefits just as new administrations that banks can offer, and these have been influenced by a bank's general productivity of tasks. Thirdly, it helps strategy makers to figure out strategies that affect the overall financial business. The efficiency scores of the Shariah banking sector are quite important to pick input and output variables (Mlima and Hjalmarsson, 2002).

Given such a scenario, this study has emphasized two major aspects. Firstly, to estimate the technical efficiency of the banking sector in the selected countries from different regions of the Islamic world and compare the efficiency of these selected countries with each other. The countries include Brunei Darussalam, Malaysia, Jordan, Indonesia, Pakistan, Turkey, Saudi Arabia, and the UAE. Secondly, to 
discover the factors that tend to determine the technical efficiency of Islamic banks in the sample of selected Islamic countries. This exploration would give a more extensive financial framework to assess technical efficiencies of Islamic banks and it helps policymakers, government agents, managers, and other stakeholders and aids them to make crucial decisions like a merger, absorption, acquisition, and takeover.

The rest of the study is organized as under. Section 2 presents a brief review of literature on technical efficiency and its determinants. Section 3 elaborates the model, data and methods. Section 4 presents findings with discussion while the section 5 leads to conclusions, policy implications, and an agenda for the future.

\section{Review of Literature}

An extensive study of the literature exists that covers the area of bank efficiency. Table- 1 below provides an overview of studies on determinants of technical efficiency of Islamic banks.

Table 1: Review of Assorted Studies

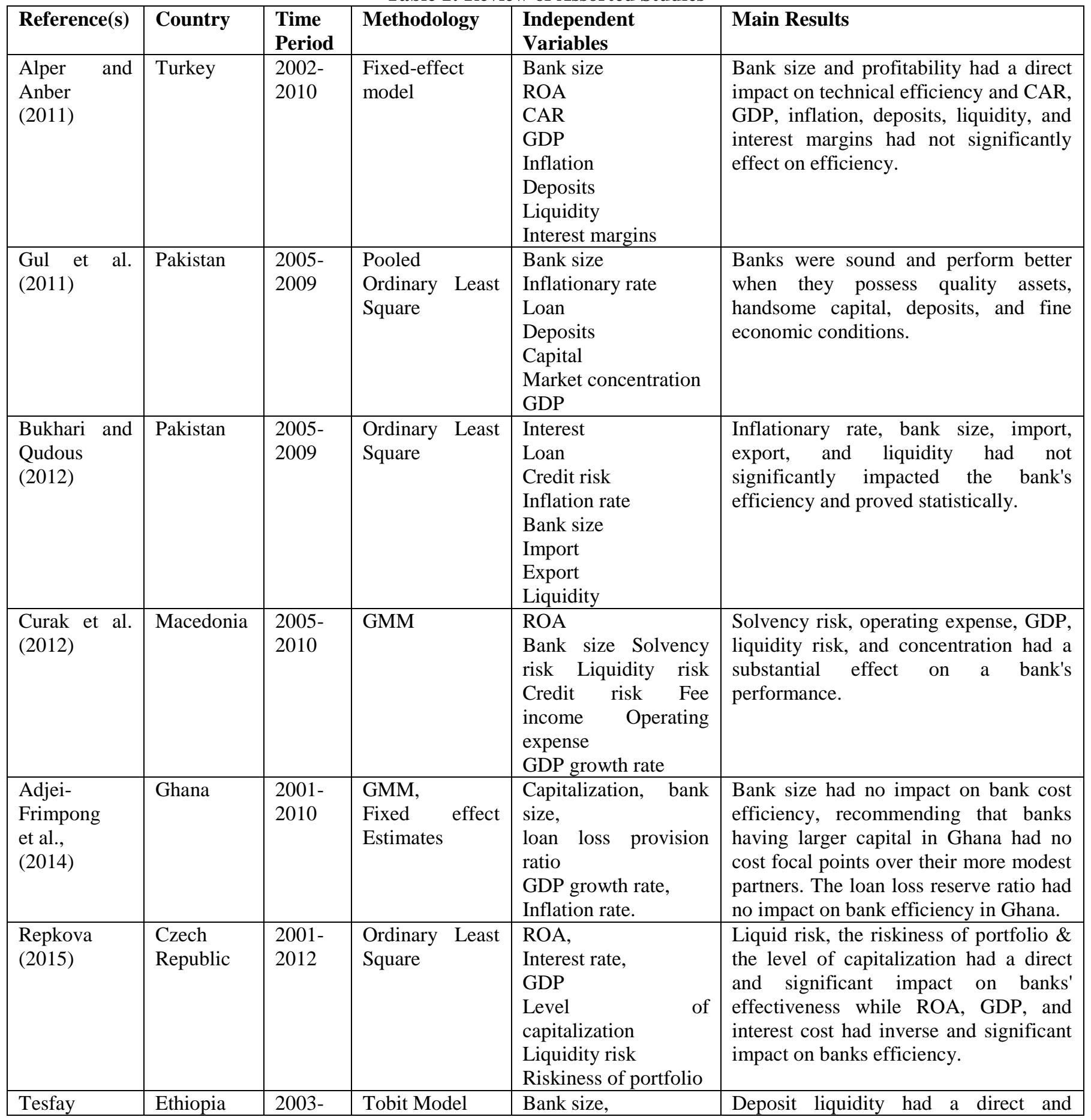




\begin{tabular}{|c|c|c|c|c|c|}
\hline (2016) & & 2012 & & $\begin{array}{l}\text { Deposits, } \\
\text { Liquidity, } \\
\text { Loan quality, } \\
\text { Profitability, } \\
\text { Operating expenses }\end{array}$ & $\begin{array}{l}\text { significant impact on bank efficiency. } \\
\text { Whereas, bank size had an inverse and } \\
\text { significant impact on bank proficiency. }\end{array}$ \\
\hline $\begin{array}{l}\text { Sari et al., } \\
(2017)\end{array}$ & Indonesia & $\begin{array}{l}2012- \\
2014\end{array}$ & Tobit Model & $\begin{array}{l}\text { ROA } \\
\text { Bank size } \\
\text { CAR } \\
\text { NPL } \\
\end{array}$ & $\begin{array}{l}\text { Foreign banks had the efficiency the } \\
\text { highest compared to local selected } \\
\text { banks. ROA and size had a positive and } \\
\text { strong impact on efficiency. }\end{array}$ \\
\hline $\begin{array}{l}\text { Kamarudin } \\
\text { et al. } \\
\text { (2019) }\end{array}$ & Malaysia & $\begin{array}{l}2006- \\
2015\end{array}$ & $\begin{array}{l}\text { Ordinary Least } \\
\text { Square, } \\
\text { Panel GLS }\end{array}$ & $\begin{array}{l}\text { Bank size } \\
\text { Capitalization level, } \\
\text { Asset quality, } \\
\text { Liquidity } \\
\text { Management quality, } \\
\text { Bank market power }\end{array}$ & $\begin{array}{l}\text { The efficiency of foreign Islamic banks } \\
\text { was more as equated to local Islamic } \\
\text { banks. Liquidity, bank market force, and } \\
\text { quality of management have a } \\
\text { significant impact on the efficiency of } \\
\text { the local Islamic bank of Malaysia. }\end{array}$ \\
\hline $\begin{array}{l}\text { Le } \\
(2020)\end{array}$ & Vietnam & $\begin{array}{l}2015- \\
2018\end{array}$ & Tobit Model & $\begin{array}{l}\text { Branch size } \\
\text { Brach age } \\
\text { Branch transaction } \\
\text { point } \\
\text { CAR } \\
\text { Cost } \\
\text { Credit quality } \\
\text { Economic growth } \\
\text { Income per capita } \\
\text { Population } \\
\end{array}$ & $\begin{array}{l}\text { Bank scale-related factors, capital } \\
\text { adequacy, credit quality, time-specific } \\
\text { and region had a significant impact on } \\
\text { retail banking efficiency. }\end{array}$ \\
\hline $\begin{array}{l}\text { Octrina et al. } \\
\text { (2021) }\end{array}$ & Indonesia & $\begin{array}{l}2011- \\
2019\end{array}$ & $\begin{array}{l}\text { Common Effect } \\
\text { Model } \\
\text { Regression }\end{array}$ & $\begin{array}{l}\text { Bank size } \\
\text { CAR } \\
\text { NPF } \\
\text { FDR ratio } \\
\text { Net operating profit } \\
\text { Inflation } \\
\text { GDP }\end{array}$ & $\begin{array}{l}\text { Factors affecting Islamic banking } \\
\text { efficiency in Indonesia were bank size, } \\
\text { Capital Adequacy Ratio (CAR), Non- } \\
\text { Performing Finance (NPF), and } \\
\text { Financing to Deposit Ratio (FDR), } \\
\text { while other factors are not influential. }\end{array}$ \\
\hline
\end{tabular}

The review of the literature shows that many of the studies have employed a non-parametric approach, Data Envelopment Analysis (DEA) to calculate technical efficiency and conclude that Islamic banks are more technically efficient in different countries of the world like Saudi Arabia, the UAE, Malaysia, and Indonesia during and after the worldwide financial crisis. These studies have used total deposits, assets, equity, capital, payroll cost, general overheads, and operating cost as input while income (fee-based, finance based and investment based), investments (Shariah-based), Assets (liquid assets, securities earning assets), loan and advances as output.

\section{Model, Data and Methodology Model Specification}

This study is based on two models. In the first model, Data Envelopment Analysis is employed to assess the technical efficiency of the Islamic banking sector of the selected Islamic countries. In the second model, the determinants of technical efficiency of Islamic banks have been explored. Moreover, we have employed the production approach.

\section{Model 1: Measurement of Technical Efficiency}

Technical Efficiency = Output/ Input

Outputs = Revenue, financing (Murābahah, Tawwaruq, Ijārah, Salam, Mushārakah, Wakālah, Qarḍ e Hassan, and Diminishing Mushārakah) in different projects.

Inputs $=$ No of Employees, Capital and Reserves, Operating Cost and

The choice of inputs and outputs is determined by extant literature, theoretical considerations, and 
accessibility of data. The number of employees includes employees and staff members currently employed and are the human resources who take part in the management that help in the creation of finance. Capital and reserves include nominal capital (balance sheet capital), revaluation surplus, inappropriate profit, and long-term reserves maintained by the Islamic banking sector which is used as a source of financing activities and is regarded as one of the major contributors. While the operating cost of Islamic banks includes all the direct and indirect expenses like staff expenses, depreciation, and other operating expenses of the Islamic banking sector.

Revenues are finance-based, investment-based, fees-based, and other sources. Financing includes Murābahah, Tawwaruq, Ijārah, Salam, Mushārakah, Wakālah, Qarḍ e Hassan, and Diminishing Mushārakah.

\section{Input and Output Specification}

Table 2 provides details about the input and output variables.

Table 2: Input and Output Variables

\begin{tabular}{|l|l|}
\hline Variable & Description \\
\hline Inputs & All administrative Employees working in the banks \\
\hline Number of employees & Capital and reserves other than funds and liabilities \\
\hline Capital and Reserves & Administrative expenses, staff expenses \\
\hline Operating costs & Finance-based, investment-based, and fees-based income \\
\hline Outputs & $\begin{array}{l}\text { Total financing, (Murābahah, Ijārah, Salam, Mushārakah, Wakālah, } \\
\text { Qarḍ e Hassan, and Diminishing Mushārakah) }\end{array}$ \\
\hline Financing &
\end{tabular}

\section{Model 2: Determinants of Technical Efficiency of Islamic Banks}

This model includes several bank-specific and macroeconomic factors to determine the technical efficiency of the Islamic banking sector.

Technical efficiency $=f(G D P G, B S, Z-S C O R E, C A R, R O E, L A R)$

The econometric equation is elaborated as:

$$
\mathrm{TE}_{\mathrm{it}}=\beta_{0}+\beta_{1} G D P G_{i t}+\beta_{2} B S_{i t}+\beta_{3} Z S_{i t}+\beta_{4} C A R_{i t}+\beta_{5} R O E_{i t}+\beta_{6} L A R_{i t}+\varepsilon_{i t}
$$

\begin{tabular}{|l|l|}
\hline \multicolumn{2}{l}{ Table 3: Description of Variables } \\
\hline Variable & Description \\
\hline GDP Growth rate (GDPG) & Quarterly growth rate of GDP \\
\hline Bank Size (BS) & Measured by the natural log of total Assets of a Bank \\
\hline Z-Score & $\begin{array}{l}\text { Measure Stability of the bank and is computed as the ratio of return } \\
\text { on assets plus Capital Adequacy ratio to standard deviation of return } \\
\text { on assets }\end{array}$ \\
\hline $\begin{array}{l}\text { Capital Adequacy Ratio } \\
\text { (CAR) }\end{array}$ & $\begin{array}{l}\text { Measure Solvency of and computed as Bank's capital to risk- } \\
\text { weighted assets }\end{array}$ \\
\hline Returns on Equity (ROE) & A measure of Profitability Profit before Tax over total equity \\
\hline Liquid Asset Ratio (LAR) & A measure of Liquid Assets over total assets \\
\hline
\end{tabular}

\section{Data and Methodology}

The data on the banking sector of Islamic countries are accessed from the database of the Islamic Financial Services Board (IFSB), macro-economic data are obtained from World Development Indicators and International Finance Statistics. The sample of selected Islamic countries includes Brunei Darussalam, Jordan, Indonesia, Pakistan, Malaysia, Turkey, Saudi Arabia, and the UAE from the first quarter of 2014 to the fourth quarter of 2019. Data Envelopment Analysis (DEA) is applied to measure the technical efficiency score and FMOLS method to investigate the determinants of technical efficiency. 


\section{Results and Discussions}

This section explains the results of the study which include the overall results on technical efficiency and regression analysis.

\section{Technical Efficiency Scores}

The technical efficiency scores of each country are shown in Table 4. The Islamic banking sector of these countries operates at a higher than 0.5 technical efficiency score. A mixed trend in the technical efficiency scores has been found in these countries. However, countries like UAE and Saudi Arabia show a higher technical efficiency score of more than 0.90 .

Some countries like Pakistan have attained a lower technical efficiency score which is 0.53 in the first quarter of 2015. This minimum output is due to some weak management decisions, less knowledge of Riba-free banking, less coordination between bank employees and the general public, or even the wastage of resources. This indicates that Pakistan is still struggling to convert their resources into desired results. UAE, Saudi Arabia, and Malaysia have also attained the maximum score of 1 at 9 times which is quite higher than other selected countries. During this period, these countries are at the peak of their technical efficiency scores, as these countries have used their employees, capital and reserves, and operating cost to produce maximum output in form of revenue and financing. This indicates that these countries have sound financial policies, have strong coordination between employees and the customers, better use of operation cost which enhances the banking activities in these regions.

Table 4: Technical Efficiency Scores by CRS

\begin{tabular}{|c|c|c|c|c|c|c|c|c|}
\hline & 1 & 2 & 3 & 4 & 5 & 6 & 7 & 8 \\
\hline Country & $\begin{array}{l}\text { Brunei } \\
\text { Darussalam }\end{array}$ & Indonesia & Jordan & Malaysia & Pakistan & Turkey & $\begin{array}{l}\text { Saudi } \\
\text { Arabia }\end{array}$ & UAE \\
\hline 2014-Q1 & 1 & 1 & 0.84 & 0.87 & 0.64 & 0.8 & 0.9 & 0.9 \\
\hline 2014-Q2 & 0.89 & 1 & 0.95 & 0.88 & 1 & 0.77 & 0.93 & 0.92 \\
\hline 2014-Q3 & 0.87 & 0.98 & 0.92 & 0.92 & 0.64 & 0.79 & 0.89 & 0.96 \\
\hline 2014-Q4 & 0.85 & 1 & 0.99 & $\overline{1}$ & 0.83 & 0.8 & 1 & 0.96 \\
\hline $\begin{array}{l}\text { Annual average } \\
\text { (2014) }\end{array}$ & 0.9 & 1 & 0.93 & 0.92 & 0.78 & 0.79 & 0.93 & 0.94 \\
\hline 2015-Q1 & 0.94 & 0.94 & 0.96 & 0.96 & 0.53 & 0.83 & 0.92 & 0.92 \\
\hline 2015-Q2 & 0.94 & 0.96 & 0.98 & 0.97 & 0.65 & 0.81 & 0.92 & 0.96 \\
\hline 2015-Q3 & 0.91 & 0.91 & 0.96 & 1 & 0.64 & 0.85 & 1 & 0.99 \\
\hline 2015-Q4 & 1 & 1 & 0.98 & 1 & 0.76 & 0.84 & 0.98 & 1 \\
\hline $\begin{array}{ll}\text { Annual } & \text { average } \\
(2015) & \\
\end{array}$ & 0.95 & 0.95 & 0.97 & 0.98 & 0.64 & 0.83 & 0.96 & 0.97 \\
\hline 2016-Q1 & 1 & 0.77 & 0.97 & 0.96 & 0.66 & 0.82 & 0.98 & 1 \\
\hline 2016-Q2 & 1 & 0.82 & 1 & 0.98 & 0.7 & 0.83 & 0.99 & 0.96 \\
\hline 2016-Q3 & 0.97 & 0.84 & 1 & 0.97 & 0.69 & 0.8 & 0.99 & 0.97 \\
\hline 2016-Q4 & 0.85 & 0.96 & 1 & 1 & 0.8 & 0.85 & 0.98 & 1 \\
\hline $\begin{array}{ll}\text { Annual } & \text { average } \\
(2016) & \\
\end{array}$ & 0.95 & 0.85 & 0.99 & 0.98 & 0.71 & 0.83 & 0.99 & 0.98 \\
\hline 2017-Q1 & 0.89 & 0.76 & 0.96 & 0.98 & 0.79 & 0.85 & 0.98 & 0.99 \\
\hline 2017-Q2 & 1 & 0.79 & 0.98 & 0.99 & 0.8 & 0.85 & 1 & 1 \\
\hline 2017-Q3 & 0.95 & 1 & 0.98 & 0.99 & 0.83 & 0.88 & 1 & 1 \\
\hline 2017-Q4 & 0.93 & 0.93 & 1 & 1 & 0.92 & 0.92 & 1 & 1 \\
\hline Annual & 0.94 & 0.87 & 0.98 & 0.99 & 0.84 & 0.87 & 0.99 & 1 \\
\hline
\end{tabular}




\begin{tabular}{|l|l|l|l|l|l|l|l|l|}
$\mathbf{( 2 0 1 7 )}$ & & & & & & & \\
\hline 2018-Q1 & 0.88 & 0.71 & 0.92 & 1 & 0.93 & 0.91 & 1 & 1 \\
\hline $\mathbf{2 0 1 8 - Q 2}$ & 0.85 & 0.69 & 0.96 & 1 & 0.9 & 0.94 & 0.98 & 1 \\
\hline 2018-Q3 & 0.86 & 0.78 & 1 & 1 & 0.94 & 1 & 1 & 0.99 \\
\hline $\mathbf{2 0 1 8 - Q 4}$ & 0.85 & 0.91 & 1 & 1 & 1 & 0.96 & 1 & 1 \\
\hline $\begin{array}{l}\text { Annual average } \\
\text { (2018) }\end{array}$ & $\mathbf{0 . 8 8}$ & $\mathbf{0 . 7 1}$ & $\mathbf{0 . 9 2}$ & $\mathbf{1}$ & $\mathbf{0 . 9 3}$ & $\mathbf{0 . 9 1}$ & $\mathbf{1}$ & $\mathbf{1}$ \\
\hline $\mathbf{2 0 1 9 - Q 1}$ & 1 & 0.74 & 0.95 & 0.96 & 0.96 & 1 & 1 & 0.98 \\
\hline $\mathbf{2 0 1 9 - Q 2}$ & 0.89 & 0.82 & 0.98 & 0.98 & 0.92 & 1 & 0.96 & 0.99 \\
\hline $\mathbf{2 0 1 9 - Q 3}$ & 0.9 & 0.87 & 0.97 & 0.99 & 0.96 & 0.97 & 1 & 1 \\
\hline $\mathbf{2 0 1 9 - Q 4}$ & 0.88 & 1 & 0.99 & 1 & 1 & 1 & 1 & 1 \\
\hline $\begin{array}{l}\text { Annual Average } \\
(\mathbf{2 0 1 9 )}\end{array}$ & $\mathbf{0 . 9 2}$ & $\mathbf{0 . 8 6}$ & $\mathbf{0 . 9 7}$ & $\mathbf{0 . 9 8}$ & $\mathbf{0 . 9 6}$ & $\mathbf{0 . 9 9}$ & $\mathbf{0 . 9 9}$ & $\mathbf{0 . 9 9}$ \\
\hline Average & $\mathbf{0 . 9 2}$ & $\mathbf{0 . 8 8}$ & $\mathbf{0 . 9 7}$ & $\mathbf{0 . 9 7}$ & $\mathbf{0 . 8 1}$ & $\mathbf{0 . 8 8}$ & $\mathbf{0 . 9 8}$ & $\mathbf{0 . 9 8}$ \\
\hline $\begin{array}{l}\text { Frequency } \\
\text { Efficiency }\end{array}$ & 6 & 6 & 5 & 9 & 3 & 3 & 9 & 9 \\
\hline
\end{tabular}

\section{Descriptive Statistics and Correlation Analysis}

Table 5 exhibits descriptive statistics of variables. The mean value of technical efficiency points out that the average score in Islamic countries is 0.92 . The mean of technical efficiency denotes that on average, a banking sector has a low cost of operations as compared to revenue and financing. This also indicates that these banks used $92 \%$ of their resources to produce output on average. Likewise, the average growth rate of GDP is $3.2 \%$ with a Standard deviation of 2.88. The mean value of Bank size is $\$ 64,626$ million with a standard deviation of $\$ 64,286$. The mean value of $\mathrm{Z}$-Score is 36.79 with a standard deviation of 7.33. The mean value of CAR is $2.38 \%$ with a standard deviation of 5.78 . The mean value of ROE is 0.15 with a standard deviation of 0.05 . The mean value of LAR is 0.29 with a standard deviation of 0.15 .

Table 5: Descriptive Statistics of Key Variables (2014-2019)

\begin{tabular}{|l|l|l|l|l|}
\hline & Mean & Maximum & Minimum & Standard Deviation \\
\hline TE & 0.92 & 1.00 & 0.53 & 0.09 \\
\hline GDPG & 3.21 & 11.60 & -9.10 & 2.88 \\
\hline BS & 64626 & 199934 & 6301 & 64286 \\
\hline ZSCORE & 36.79 & 50.47 & 0.00 & 7.33 \\
\hline CAR & 2.38 & 21.30 & 0.13 & 5.78 \\
\hline ROE & 0.15 & 0.36 & 0.04 & 0.05 \\
\hline LAR & 0.29 & 0.72 & 0.00 & 0.15 \\
\hline
\end{tabular}

Table 6 demonstrates the correlation among variables. technical efficiency is negatively correlated with GDPG, CAR and LAR while it is positively correlated with BS, Z-Scores and ROE. technical efficiency is weakly correlated GDPG, CAR, ROE and LAR while it is moderately correlated with BS and Z-score. So, there is no strong correlation of technical efficiency with all variables.

Table 6: Correlation Analysis of Key Variables (2014-2019)

\begin{tabular}{|l|l|l|l|l|l|l|l|}
\hline Correlation & TE & GDPG & BS & Z-SCORE & CAR & ROE & LAR \\
\hline TE & 1.00 & & & & & & \\
\hline GDPG & -0.24 & 1.00 & & & & & \\
\hline BS & 0.43 & 0.05 & 1.00 & & & & \\
\hline Z-SCORE & 0.38 & -0.54 & -0.01 & 1.00 & & & \\
\hline CAR & -0.18 & 0.26 & -0.27 & 0.21 & 1.00 & & \\
\hline ROE & 0.13 & -0.05 & -0.06 & -0.32 & -0.32 & 1.00 & \\
\hline LAR & -0.15 & -0.36 & -0.46 & -0.42 & -0.42 & 0.05 & 1.00 \\
\hline
\end{tabular}




\section{Panel Unit Root Analysis}

Table 7 demonstrates panel unit root analysis results. We have employed four panel unit tests. The results show that all the variables are non-stationary at level.

\begin{tabular}{|c|c|c|c|c|c|c|c|c|c|c|c|c|}
\hline \multicolumn{13}{|c|}{ Panel Unit Root Test at Level } \\
\hline \multirow[b]{2}{*}{ Var } & \multicolumn{4}{|c|}{ Intercept } & \multicolumn{4}{|c|}{ Intercept and Trend } & \multicolumn{3}{|l|}{ None } & \multirow[t]{2}{*}{ Result } \\
\hline & $\begin{array}{l}\text { LLC } \\
\text { Test }\end{array}$ & $\begin{array}{l}\text { IPS } \\
\text { Test }\end{array}$ & $\begin{array}{l}\text { ADF- } \\
\text { Fisher } \\
\text { Chi- } \\
\text { Square }\end{array}$ & $\begin{array}{l}\text { PP- } \\
\text { Fisher } \\
\text { Chi- } \\
\text { Square }\end{array}$ & $\begin{array}{l}\text { LLC } \\
\text { Test }\end{array}$ & $\begin{array}{l}\text { IPS } \\
\text { Test }\end{array}$ & $\begin{array}{l}\text { ADF- } \\
\text { Fisher } \\
\text { Chi- } \\
\text { Square }\end{array}$ & $\begin{array}{l}\text { PP- } \\
\text { Fisher } \\
\text { Chi- } \\
\text { Square }\end{array}$ & $\begin{array}{l}\text { LLC } \\
\text { Test }\end{array}$ & $\begin{array}{l}\text { ADF- } \\
\text { Fisher } \\
\text { Chi- } \\
\text { Square }\end{array}$ & $\begin{array}{l}\text { PP- } \\
\text { Fisher } \\
\text { Chi- } \\
\text { Square }\end{array}$ & \\
\hline TE & $\begin{array}{l}-2.35 \\
(.34) \\
\end{array}$ & $\begin{array}{l}-3.11 \\
(0.40) \\
\end{array}$ & $\begin{array}{l}44.37 \\
(0.87) \\
\end{array}$ & $\begin{array}{l}84.53 \\
(0.67)\end{array}$ & $\begin{array}{l}-2.98 \\
(0.14)\end{array}$ & $\begin{array}{l}-3.44 \\
(0.00)\end{array}$ & $\begin{array}{l}39.29 \\
(0.01)\end{array}$ & $\begin{array}{l}78.38 \\
(0.98)\end{array}$ & $\begin{array}{l}2.33 \\
(0.99)\end{array}$ & $\begin{array}{l}3.57 \\
(0.99)\end{array}$ & $\begin{array}{l}3.56 \\
(0.99)\end{array}$ & NS \\
\hline GDPG & $\begin{array}{l}-0.58 \\
(0.27)\end{array}$ & $\begin{array}{l}-1.57 \\
(0.05) \\
\end{array}$ & $\begin{array}{l}21.94 \\
(0.14)\end{array}$ & $\begin{array}{l}29.52 \\
(0.02)\end{array}$ & $\begin{array}{l}0.18 \\
(0.57)\end{array}$ & $\begin{array}{l}-1.67 \\
(0.04)\end{array}$ & $\begin{array}{l}27.08 \\
(0.04)\end{array}$ & $\begin{array}{l}30.75 \\
(0.04)\end{array}$ & $\begin{array}{l}-1.87 \\
(0.03)\end{array}$ & $\begin{array}{l}32.11 \\
(0.09)\end{array}$ & $\begin{array}{l}37.25 \\
(0.01)\end{array}$ & NS \\
\hline BS & $\begin{array}{l}-0.71 \\
(0.23)\end{array}$ & $\begin{array}{l}2.03 \\
(0.97) \\
\end{array}$ & $\begin{array}{l}9.61 \\
(0.88)\end{array}$ & $\begin{array}{l}9.75 \\
(0.87)\end{array}$ & $\begin{array}{l}1.06 \\
(0.85)\end{array}$ & $\begin{array}{l}0.51 \\
(0.85)\end{array}$ & $\begin{array}{l}11.36 \\
(0.78)\end{array}$ & $\begin{array}{l}9.99 \\
(0.86)\end{array}$ & $\begin{array}{l}5.45 \\
(1.00)\end{array}$ & $\begin{array}{l}1.01 \\
(1.00)\end{array}$ & $\begin{array}{l}0.86 \\
(1.00)\end{array}$ & NS \\
\hline ZSCORE & $\begin{array}{l}0.85 \\
(0.80) \\
\end{array}$ & $\begin{array}{l}1.26 \\
(0.00) \\
\end{array}$ & $\begin{array}{l}8.97 \\
(0.91) \\
\end{array}$ & $\begin{array}{l}29.61 \\
(0.02) \\
\end{array}$ & $\begin{array}{l}-0.47 \\
(0.31) \\
\end{array}$ & $\begin{array}{l}0.31 \\
(0.62) \\
\end{array}$ & $\begin{array}{l}24.02 \\
(0.08)\end{array}$ & $\begin{array}{l}35.61 \\
(0.00) \\
\end{array}$ & $\begin{array}{l}1.13 \\
(0.01) \\
\end{array}$ & $\begin{array}{l}6.47 \\
(0.98) \\
\end{array}$ & $\begin{array}{l}7.72 \\
(0.95) \\
\end{array}$ & NS \\
\hline CAR & $\begin{array}{l}4.37 \\
(1.00)\end{array}$ & $\begin{array}{l}0.40 \\
(0.00)\end{array}$ & $\begin{array}{l}12.98 \\
(0.67)\end{array}$ & $\begin{array}{l}103.99 \\
(0.00)\end{array}$ & $\begin{array}{l}6.27 \\
(1.00)\end{array}$ & $\begin{array}{l}-1.49 \\
(0.06)\end{array}$ & $\begin{array}{l}26.11 \\
(0.05)\end{array}$ & $\begin{array}{l}299.51 \\
(0.00)\end{array}$ & $\begin{array}{l}1.30 \\
(0.90)\end{array}$ & $\begin{array}{l}4.45 \\
(0.99)\end{array}$ & $\begin{array}{l}7.72 \\
(0.95)\end{array}$ & NS \\
\hline ROE & $\begin{array}{l}1.10 \\
(0.86)\end{array}$ & $\begin{array}{l}0.22 \\
(0.80)\end{array}$ & $\begin{array}{l}16.14 \\
(0.44)\end{array}$ & $\begin{array}{l}28.92 \\
(0.02)\end{array}$ & $\begin{array}{l}-1.00 \\
(0.09)\end{array}$ & $\begin{array}{l}-1.16 \\
(0.12)\end{array}$ & $\begin{array}{l}23.30 \\
(0.10)\end{array}$ & $\begin{array}{l}122.84 \\
(0.89)\end{array}$ & $\begin{array}{l}0.56 \\
(0.80)\end{array}$ & $\begin{array}{l}6.84 \\
(0.97)\end{array}$ & $\begin{array}{l}7.87 \\
(0.95)\end{array}$ & NS \\
\hline LAR & $\begin{array}{l}-1.94 \\
(0.21)\end{array}$ & $\begin{array}{l}-1.55 \\
(0.53)\end{array}$ & $\begin{array}{l}22.50 \\
(0.12)\end{array}$ & $\begin{array}{l}26.10 \\
(0.51)\end{array}$ & $\begin{array}{l}-3.25 \\
(0.34)\end{array}$ & $\begin{array}{l}-2.33 \\
(0.10)\end{array}$ & $\begin{array}{l}31.52 \\
(0.40)\end{array}$ & $\begin{array}{l}32.76 \\
(0.51)\end{array}$ & $\begin{array}{l}-1.22 \\
(0.11)\end{array}$ & $\begin{array}{l}12.07 \\
(0.73)\end{array}$ & $\begin{array}{l}12.79 \\
(0.68)\end{array}$ & NS \\
\hline
\end{tabular}

Table 7: Results of Panel Unit Root

Note: NS means non-Stationary

\section{Panel Cointegration Analysis}

Kao, Johansen, Fisher, and Pedroni residual co-integration tests are used to find the existence of a longrun association between variables. Table 8 demonstrates Kao co-integration analysis results.

Table 8: Kao Residual Co-integration Test

\begin{tabular}{|l|l|l|}
\hline Model & ADF t-Statistic & ADF Prob. \\
\hline TE/GDPG, LOG(BS), Z-SCORE, CAR, ROE, LAR & -2.91 & 0.00 \\
\hline
\end{tabular}

The ADF p-value obtained from the test is 0.00 which is statistically significant. So, we can reject the null hypothesis. Based on test findings, it can be concluded that there is an existence of a long-run association.

Table 9 demonstrates Johansen-Fisher panel cointegration test results. The results of this test also the existence of a long-run association.

Table 9: Johansen-Fisher Panel Co-integration Test

\begin{tabular}{|l|l|l|l|l|}
\hline $\begin{array}{l}\text { Hypothesized } \\
\text { No. of CE(s) }\end{array}$ & $\begin{array}{l}\text { Fisher Stat. } \\
\text { (Trace test) }\end{array}$ & Prob. & $\begin{array}{l}\text { Fisher Stat. } \\
\text { (Max-Eigen test) }\end{array}$ & Prob. \\
\hline None & 315.3 & 0.00 & 394.7 & 0.00 \\
\hline At most 1 & 209.1 & 0.00 & 123.0 & 0.00 \\
\hline At most 2 & 110.6 & 0.00 & 61.54 & 0.00 \\
\hline At most 3 & 87.56 & 0.00 & 53.96 & 0.00 \\
\hline At most 4 & 61.58 & 0.00 & 45.34 & 0.00 \\
\hline At most 5 & 32.52 & 0.00 & 22.89 & 0.11 \\
\hline At most 6 & 38.55 & 0.00 & 38.55 & 0.00 \\
\hline
\end{tabular}

Table 10 demonstrates Pedroni residual cointegration test results. This test also identifies the long-run association. This result of $p$-values shows the rejection of the null hypothesis. So, all tests confirm the cointegration and have a long-run relationship. Fully Modified Least Square (FMOLS) analysis results are shown in Table 11. It is commonly believed that the GDP growth rate is a macroeconomic variable. Growth may lead to an overall increase in banking sector efficiency, resulting in a direct relationship between GDP and efficiency. A conceivable clarification may be that a higher level of GDP growth rate builds business action and boosts business execution among borrowers and business visionaries where better performance results in falling the default risk and risk premium that empower banks to increase 
their profit margins. But an inverse relationship has also been witnessed in the literature.

Table 10: Pedroni Residual Co-integration Test

\begin{tabular}{|l|l|l|l|l|}
\hline Alternative Hypothesis & Statistic & Prob. & $\begin{array}{l}\text { Weighted } \\
\text { Statistic }\end{array}$ & Prob. \\
\hline Common AR coefficients (within-dimension) \\
\hline Panel v-Statistic & 0.10 & 0.46 & -0.62 & 0.73 \\
\hline Panel rho-Statistic & 0.60 & 0.72 & 1.73 & 0.95 \\
\hline Panel PP-Statistic & -3.17 & 0.00 & -2.64 & 0.00 \\
\hline Panel ADF-Statistic & 0.05 & 0.52 & -1.99 & 0.02 \\
\hline Common AR coefficients (Between-dimension) & 2.78 & 0.99 & & \\
\hline Group rho-Statistic & -4.74 & 0.00 & & \\
\hline Group PP-Statistic & -2.83 & 0.00 & & \\
\hline Group ADF-Statistic &
\end{tabular}

In this study, the GDP growth rate has a negative but significant relationship with the technical efficiency of Islamic banks. The negative association between GDP and technical efficiency may be justified on the following grounds: Firstly, this may be due to the small share of Islamic banks in the services industry in the GDP of these selected Islamic countries. This small share indicates that an increase in GDP growth rate has an inverse relation with technical efficiency. Secondly, due to consumption-oriented societies, people in these countries spend more than savings and investment. Therefore, banking channel is not used much in these countries. Thirdly, less financial inclusion, financial literacy and monetization, people do not use banking channel. Fourthly, economic growth boosts the business environment which creates the demand for loanable funds in the economy and banks compete with one another to supply the loanable funds to investors and resultantly they have to reduce their profit margins which decrease the efficiency of the banks. Fifthly, if the GDP growth rate is volatile, banks have to face bad debts or bank run which may hurt bank efficiency (Pasiouras et al., 2007). Sixthly, with an increase in GDP growth, aggregate demand accelerates, and inflation occurs in the economy. If an anticipated or unanticipated inflation exists in the economy, people would spend more by recognizing the time value of money, so consumption expenditures increase and investment expenditures fall which reduce the importance of financial institutions and the efficiency of these institutions is badly affected. Our results are in accordance with the studies by Onen and Tunik (2017); Repkova (2015); Chortareas et.al (2012); Tan and Floros (2012). However, some studies have also found a positive association between GDP and bank efficiency Banna et al., (2019a); Tarus et al., (2012) ; Grigorian and Manole (2006).

Table 11: Panel Fully Modified Least Squares (FMOLS) Analysis

\begin{tabular}{|l|l|l|l|l|}
\hline Dependent Variable: Technical Efficiency (TE) \\
\hline Variable & Coefficient & Std. Error & t-Statistic & Prob. \\
\hline GDPG & -0.06 & 0.00 & -7.72 & 0.00 \\
\hline LOG(BS) & 0.08 & 0.00 & 106.65 & 0.00 \\
\hline ZSCORE & -0.01 & 0.00 & -7.72 & 0.00 \\
\hline CAR & -0.95 & 0.00 & -698.30 & 0.00 \\
\hline ROE & 0.76 & 0.00 & 864.28 & 0.00 \\
\hline LAR & 0.19 & 0.00 & 136.21 & 0.00 \\
\hline
\end{tabular}

Bank Size has appeared with a positive sign. This indicates that banks may take advantage of their assets to reduce the cost which improves the profitability and efficiency of banks. Larger banks are capable to mobilize more funds in generating high returns for their depositors and equity holders due to diversification. Many assets may capture greater market power and the ability to secure funding at a low cost. Several other factors like economies of scale, learning curve, proper management of resources influence the banks' efficiency. Many studies have found a positive association between bank size and technical efficiency see, for example, Octrina et al., (2021); Sari et al., (2017); Smirlock (1985). However, some studies have found a negative link between bank size and technical efficiency see, for example, Tesfay (2016); Alper and Anbar (2011); Athanasoglou et al., (2008) and Goddard et al., (2004). The 
inverse relation between banks size and efficiency might be due to diseconomies of scale.

Z-score indicates the negative and significant association with technical efficiency. Z-score is a measure of the stability of the bank. A Z-score is a ratio of return on assets plus capital adequacy ratio to standard deviation of return on assets, so if the standard deviation of return on assets increases, it decreases the Zscores, and stability falls and eventually efficiency of banks deteriorates. From the descriptive statistics, we may observe that Z-score has the largest standard deviation among all variables, so this supports that Z-score falls in the case of Islamic countries and efficiency falls. Our results are in line with Demirguc and Huizinga (1999). Some studies find the positive link between Z-score and technical efficiency see, for example, Beltratti and Paladino (2015); Djalilov and Piesse (2016).

Capital Adequacy Ratio (CAR) is negative and statistically highly significant. The possible reason for this negative association is capital of Islamic banks is insufficient to secure against future risk. So, the banks are covering their risks (in the form of an increase in bad debts, fluctuation in the value of securities) from their capital. Our results correspond with some studies by Ramli and Hakin (2017); Karimah et al., (2016). Though, some studies have pointed out a positive relationship, for example, Octrina et al., (2021); Le (2020); Kamaruddin et al., (2019).

Returns on equity (ROE) turns out with a positive sign and statistically highly significant. The positive relation indicates that banks are retaining more equity and earn more non-interest income. ROE depends on the capitalization of banks. At the point when a bank is highly capitalized, this shows that capital is not disbursed to investors and held for future investments. Banks utilize the capital more productively and have better financial leverage consequently returns on equity accelerates and the efficiency of banks improves. These results are following Akhtar (2013); Sufian and Noor (2009); Hassan (2006); Jackson and Fethi (2000).

Liquid Asset Ratio (LAR) is positive and statistically significant. This indicates that banks hold more liquid assets to mitigate upcoming risks. This direct link helps to understand the minimization of systematic risk reduced by liquid assets. Holding more illiquid assets causes an increase in systematic risk. Bourke (1989) finds a positive significant connection between bank liquidity and efficiency. Nevertheless, in times of insecurity, banks may decide to build their money holding to relieve hazards. Liquid assets may be served as the security for payment of demanded liabilities, more especially as evidence of prudence. Banks are needed to have a significant liquid asset while on the other side; they are expected to be profitable for survival. However, liquidity and profitability may be negatively associated. Holding more liquid assets to fulfil short-term liabilities causes inverse relation on profitability which reduces efficiency. This result is matched with Lin et al., (2012), who have inferred that high liquid banks have low margins and inverse efficiency. Moreover, Fungacova and Poghosyan (2011); Naceur and Kandil (2009) have also found a negative relationship between liquidity and profitability.

\section{Conclusions and Policy Implications}

This study aims to examine the determinants of technical efficiency of the Islamic banking sector for a selected sample of Islamic countries between 2014-Q1 to 2019-Q4. The technical efficiency estimates of banks are assessed by using a non-parametric DEA methodology. These bank efficiency scores are further investigated with the help of some determinants by applying Cointegration analysis and Fully Modified Least Squares (FMOLS) analysis.

The results of technical efficiency uncover the average technical efficiency scores of some countries like Pakistan are below the overall technical efficiency scores average suggesting that the banks in these countries are falling behind in exploiting their human and financial resources. The countries like UAE and Saudi Arabia are prominent in the sample having higher technical efficiency scores as compared to other countries. The average technical efficiency score is 0.98 for each of these countries. This recommends that the banks of these countries apply their maximum capacity of inputs to produce outputs in terms of revenue and financing. Malaysia is the only country whose frequency of efficiency score is equal to UAE and Saudi Arabia. 
The relationship between the technical efficiency of banks and other variables like GDP growth rate, Bank size, Z-score, Capital Adequacy Ratio, ROE, and Liquidity Asset Ratio is also examined. The results of the Panel Fully Modified Least Squares (FMOLS) analysis indicate that the GDP growth rate, $\mathrm{CAR}$, and Z-score have a negative and significant impact on the technical efficiency of these banks. while the Bank size, returns on equity and liquid asset ratio have a positive and significant influence on the technical efficiency of these banks.

The study endures some valuable policy implications both for managers of the banks as well as policymakers and regulators of the countries under investigation.

- Some Islamic banks are technically efficient, and some have appeared technically less or inefficient. For example, Pakistan and Turkey are not much efficient. There is a need to improve their efficiency by utilizing their inputs optimally.

- The banks need to seek activities that may empower them to get them efficient by exploiting their Shariah-compliant products.

- The study provides evidence that the technical efficiency of Islamic banks improves with an increase in bank size. Hence, managers of these selected Islamic banks may strive to attain optimal utilization of the capacities that they have like inputs or resources and improve their managerial expertise particularly on exercising efficient allocation of scarce resources. By optimal utilization of their assets, they would be in a better position to achieve economies of scale for their banks.

- Z-score has an adverse impact on technical efficiency. Based on these findings, it is recommended that volatility in returns on assets may be minimized by improving the economic environment.

- The finding indicates bank's capitalization reduces technical efficiency. It is recommended that operating costs may be reduced which would increase the bank's profit because of capital increases. The banks may also improve their level of capitalization by increasing the equity level relative to the respective total assets.

- GDP growth rate influences technical efficiency adversely. This recommends that banks should not go for cut-throat competition as the business environment flourish.

- Technical efficiency is positively correlated with the return on equity. Thus, efforts may be made by managers internally to improve the return on equity.

\section{References}

Abeka, M., Andoh, E., Gatsi, J. G., \& Kawor, S. (2021). Financial development and economic growth nexus in SSA economies: The moderating role of telecommunication development. Cogent Economics \& Finance, 9(1), 1862395.

Abu-Bader, S., \& Abu-Qarn, A. S. (2008). Financial development and economic growth: The Egyptian experience. Journal of Policy Modeling, 30(5), 887e898.

Adjei - Frimpong, K., Gan, C., and Hu, B. (2014). Cost Efficiency of Ghana's Banking industry: A Panel Data Analysis, The International Journal of Business and Finance Research, 8 (2), $69-86$.

Akhtar, M. H, (2013). After the financial crisis: a cost-efficiency analysis of banks from Saudi Arabia, International Journal of Islamic and Middle Eastern Finance and Management 6(4), 322-332.

Alper, D., \& Anbar, A. (2011). Bank empirical specific and macroeconomic determinants of commercial bank profitability: evidence from Turkey. Business and Economics Research Journal, 2(2), $139 \mathrm{e} 152$.

Ariff, M., \& Luc, C. (2008). Cost and profit efficiency of Chinese banks: A non-parametric analysis. China economic review, 19(2), 260-273.

Athanasoglou, P. P., Brissimis, S. N., \& Delis, M. D. (2008). Bank-specific, industry-specific and macroeconomic determinants of bank profitability. Journal of international financial Markets, Institutions and Money, 18(2), 121-136.

Aysan, A., F., Disli, M., Duygun, M., \& Ozturk, H. (2018). Religiosity versus rationality: depositor behavior in Islamic and conventional banks. Journal of Comparative Economics, 46(1).

Banna, H., Alam, M. R., Ahmad, R., \& Sari, N. M. (2020). Does Financial Inclusion Drive Islamic 
Banking Efficiency? A Post-Financial Crisis Analysis. The Singapore Economic Review.

Banna, H., Shah, S. K. B., Noman, A. H. M., Ahmad, R., \& Masud, M. M. (2019a).Determinants of SinoASEAN Banking Efficiency: How Do Countries Differ? Economies, 7(1), 13.

Barr, R. S., Seiford, L. M., \& Siems, T. F. (1994). Forecasting bank failure: A non-parametric frontier estimation approach. Recherches Economiques de Louvain, 60, 417-429.

Beltratti, A., \& Paladino, G. (2015). Bank leverage and profitability: Evidence from a sample of international banks. Review of Financial Economics, 27, 46-57.

Berger, A. N., \& Humphrey, D. B. (1997). Efficiency of financial institutions: International survey and directions for future research. European journal of operational research, 98(2), 175-212.

Bourke, P. (1989). Concentration and other determinants of bank profitability in Europe, North America and Australia. Journal of Banking \& Finance, 13(1), 65-79.

Bukhari, S. A. J., \& Qudous, R. A. (2012). Internal and external determinants of profitability of banks: Evidence from Pakistan. Interdisciplinary journal of contemporary research in business, 3(9), 1037-1058.

Chortareas, G., Garza-Garcia, J., \& Girardone, C. (2012), Competition, Efficiency, Interest Rate Margins in Latin American Banking, International Review of Financial Analysis, Vol.24, pp.93-103.

Curak, M., Poposki, K., \& Pepur, S. (2012). Profitability determinants of the Macedonian banking sector in a changing environment. Procedia-Social and Behavioral Sciences, 44, 406e416.

Demirguç-Kunt, A., and H. Huizinga. 1999. Determinants of commercial bank interest margins and profitability: Some international evidence. The World Bank Economic Review 13 (2):379-408.

Djalilov, K., \& Piesse, J. (2016). Determinants of bank profitability in transition countries: What matters most?. Research in International Business and Finance, 38, 69-82.

Fungacova, Z. \& Poghosyan, T. (2011), Determinants of Bank Interest Margins in Russia: Does Bank Ownership Matter? Economic Systems, Vol. 35, pp. 481-495.

Galindo, A. J., Schiantarelli, F., \&Weiss, A. (2007). Does financial liberalization improve the allocation of Investment? Micro evidence from developing countries. Journal of Development Economics, $83(2), 562 \mathrm{e} 587$.

Goddard, J., Molyneux, P., \& Wilson, J. O. S. (2004). The profitability of European banks: a crosssectional and dynamic panel analysis. The Manchester School, 72(3), 363e381.

Grigorian, D. A., \& Manole, V. (2006). Determinants of Commercial Bank Performance in transition: An Application of Data Envelopment Analysis. Comparative Economic Studies, 48(3), 497-522.

Gul, S., Irshad, F., \& Zaman, K. (2011). Factors affecting bank profitability in Pakistan. The Romanian Economic Journal, 14(39), 61e87.

Hassan, M. K. (2006). The X-Efficiency in Islamic Banks. Islamic Economic Studies. Vol. 13, No. 2, pp: 49-78.

Jackson, P. M., \& Fethi, M. D. (2000). Evaluating the efficiency of Turkish commercial banks: An application of DEA and Tobit Analysis.

Kamarudin, F., Sufian, F., Nassir, A. M., Anwar, N. A. M., \& Hussain, H. I. (2019). Bank efficiency in Malaysia a DEA approach. Journal of Central Banking Theory and Practice, 8(1), 133-162.

Karimah, S., Novianti, T., \& Effendi, J. (2016). Kajian efisiensi bank umum Syariah di Indonesia. Jurnal Al-Muzara'ah,4(1), 33-43.

Kavya, T. B., \& Shijin, S. (2020). Economic development, financial development, and income inequality nexus. Borsa Istanbul Review, 20(1), 80-93.

Le, T. T. D. (2020). Determinants of Retail Banking Efficiency: A case of Vietcombank branches in the Mekong-Delta region. The Journal of Asian Finance, Economics, and Business, 7(7), 439-451.

Lin, J. R., Chung, H., Hsieh, M. H., \& Wu, S. (2012). The determinants of interest margins and their effect on bank diversification: Evidence from Asian banks. Journal of Financial Stability, 8(2), 96-106.

Mlima and Hjalmarrsom (2002): Measurement of Inputs and Outputs in Banking Industry: Tanzanet Journal (2002), Volume 3(1), University of Gothenburg.

Naceur, S. B., \& Kandil, M. (2009). The impact of capital requirements on banks' cost of intermediation and performance: The case of Egypt. Journal of Economics and Business, 61(1), 70-89. 
Octrina, F., \& Mariam, A. G. S. (2021). Islamic Bank Efficiency in Indonesia: Stochastic Frontier Analysis. The Journal of Asian Finance, Economics, and Business, 8(1), 751-758.

Onen, F. K., \& Tunik, I. (2017). The determinants of efficiency in Turkish banking sector after the global finacial crisis. European Scientific Journal, 13, 471-479.

Pasiouras, F., Sifodaskalakis, E., \& Zopounidis, C. (2007). Estimating and analysing the cost efficiency of Greek cooperative banks: an application of two-stage data envelopment analysis. Working Paper. UNSPECIFIED, Bath (Unpublished).

Ramli, A., \& Hakim, A. (2017). Pemodelan efisiensi bank di Indonesia: Perbandingan antara bank Syariah dan bankkonvensional. Jurnal Bisnis dan Manajemen, 7(2), 131-148.

Ratsimalahelo, Z., \& Barry, M. D. (2010). Financial development and economic growth: Evidence from West Africa. Economics Bulletin, 30,2996e3009.

Repkova, I. (2015). Banking efficiency determinants in the Czech banking sector. Procedia Economics and Finance, 23, 191-196.

Sari, P. Z., \& Saraswati, E. (2017). The Determinant of Banking Efficiency in Indonesia (DEA Approach). Journal of Accounting and Business Education, 1(2), 208-229.

Shan, J., \& Jianhong, Q. (2006). Does financial development 'lead' economic growth? The case of China. Annals of Economics and Finance, 1,197e216.

Siriki, D. B., \& Machrafi, M. (2021). The impact of the banking sector on economic growth in Cote D'ivore from 1990 to 2019. Economic and Social Development: Book of Proceedings, 204-217.

Smirlock, M. (1985). Evidence on the (non) relationship between concentration and profitability in banking. Journal of Money, Credit, and Banking, 17(1), 69e83

Sufian, F., Mohamad Akbar Noor Mohamad Noor (2009) The determinants of Islamic banks' efficiency changes: Empirical evidence from the MENA and Asian banking sectors, International Journal of Islamic and Middle Eastern Finance and Management, Vol. 2, Issue, 2, pp: 120-138.

Tan, Y., \& Floros, C. (2012). Bank profitability and GDP growth in China: a note. Journal of Chinese Economic and Business Studies, 10(3), 267-273.

Tarus, D. K., Chekol, Y. B., \& Mutwol, M. (2012). Determinants of net interest margins of commercial banks in Kenya: A panel study. Procedia Economics and Finance, 2, 199-208.

Tesfay, T. (2016). Determinants of commercial banks efficiency: Evidence from selected commercial banks of Ethiopia. International Journal of Scientific and Research Publications, 6, 551-556. 